\title{
PENGADAAN TANAH UNTUK KEPENTINGAN UMUM DALAM PERSPEKTIF PENENTUAN IJIN LOKASI, BESARAN GANTI KERUGIAN DAN PENYELESAIAN SENGKETA YANG DITIMBULKAN
}

\author{
Oleh : \\ Muhammad Hoiru Nail \\ Email: hoirunail88@gmail.com \\ Universitas Islam Jember
}

\begin{abstract}
Abstrak
Pemerintah sebagai organisasi tertinggi dalam sebuah negara memiliki kewajiban untuk mewujudkan tujuan negara sebagaimana termaktub dalam alinea ke IV UUD NRI Tahun 1945, salah satu cara yang digunakan untuk mewujudkan hal tersebut ialah pembangunanpembangunan infrastruktur yang membutuhkan tanah sebagai bahan dasar pemenuhannya. Dalam konteks hukum agraria, tiap-tiap tanah yang ada di wilayah negara kesatuan RI memiliki hak sosial, sehingga dalam keadaan tertentu apabila negara (pemerintah) membutuhkan tanah tersebut maka selayaknya tanah tersebut wajib dilepaskan dengan persprektif pengadaan tanah untuk kepentingan umum. Berbagai macam proses pengadaan tanah untuk kepentingan umum yang tidak terlepaskan ialah penentuan ijin lokasi, besaran ganti rugi dan persoalan hukum yang timbul akibat pengadaan tanah untuk kepentingan umum, sehingga diperlukan metode penyesaian baik secara non litigasi dan litigasi.
\end{abstract}

Kata Kunci: Pengadaan tanah untuk kepentingan umum, musyawarah, ganti kerugian.

\begin{abstract}
The government as the highest organization in a country has the obligation to realize the goals of the state as stated in paragraph 4 of the indonesia constitution, one of the ways used to achive this is infrastructure development which requires lands as te basic material for its fulfillment. In the context agrarian law, land in the territory of Indonesia has social rigts, so that certain circumstances, if the goverment needs the land, it is appropriate that the land must be released for public purposed. Various kinds of land acquisition processed for the public interest that are not realesed are the determination of location permits, the amount of compensation and legal issues arising from land acquisition for the public interest, so that both non-litigation and litigation methods are needed.
\end{abstract}

Keywords: land acquisition for the public interest, discussion, compensation 


\section{PENDAHULUAN}

\subsection{Latar Belakang}

Hampir seluruh negara yang ada di belahan bumi menganggap dan mengklaim bahwa negaranya merupakan negara hukum atau negara yang pengaturan/ penyelenggaraan negaranya didasarkan pada hukum, termasuk pula Negara Kesatuan Republik Indonesia. ${ }^{1}$ Pemahaman tersebut menandakan bahwa segala bentuk tindakan yang sah yang dilakukan oleh negara haruslah berdasarkan pada hukum itu sendiri, termasuk pula dalam hal penyelenggaraan sebuah pemerintahan dalam sebuah negara.

Tanah bagi bangsa Indonesia mempunyai hubungan abadi yang harus dijaga, dikelola dan dimanfaatkan dengan baik ${ }^{2}$. Bermaknanya fungsi memiliki tanah bagi bangsa Indonesia, baik perseorangan maupun kelompok, sesungguhnya secara konstitusional telah diamanatkan melalui ketentuan dalam Pasal 33 Ayat (3) UUD NRI 1945 sebagaimana tersebut di atas kepada penguasa negara agar dapat mengatur dan mengelola penggunaan dan pemanfaatan tanah guna peningkatan kesejahteraan dan kemakmuran seluruh rakyat Indonesia.

\footnotetext{
${ }^{1}$ Pasal 1 Ayat (3) Undang-Undang Dasar Negara Republik Indonesia Tahun 1945. "Negara Indonesia adalah Negara Hukum."

${ }^{2}$ Boedi Harsono, Hukum Agraria Indonesia, Sejarah Pembentukan Undang-Undang Pokok Agraria, Isi dan Pelaksanannya, Djambatan,Jakarta, 2003, hlm. 228.
}

Negara Indonesia merupakan negara yang memiliki penduduk yang sangat padat di dunia, ${ }^{3}$ dengan bertambahnya penduduk tiap tahun tersebut tentu juga mengakibatkan adanya urbanisasi atau perpindahan penduduk dari daerah satu ke daerah lain yang notabene perpindahan tersebut tujuan utamanya ialah mendapatkan pekerjaan yang layak. Suatu daerah yang memiliki tingkat penduduk yang tinggi tentu disisi lain juga membutuhkan fasilitas umum yang dibutuhkan disisi lain pembangunan fasilitas umum itu membutuhkan tanah, tanah yang setiap waktu akan selalu berkurang.

Tanah merupakan penyokong penting dalam kehidupan manusia, tanah menjadi tempat pemukiman terbesar umat manusia dan menjadi tempat aktifitas kemanusiaan termasuk untuk agama tertentu tanah menjadi tempat terakhir seseorang beristirahat. Dilain hal saat ini tanah menjadi salah satu pilihan investasi seseorang guna mempersiapkan kebutuhan dimasa depannya nanti. ${ }^{4}$ Namun disisi lain tanah harus digunakan

${ }^{3}$ Data terakhirt yang tercacat hingga juni 2020 jumlah penduduk di Indonesia mencapai 268.583.016 jiwa.hal ini disampaikan langsung oleh direktur jenderal kependudukan dan ctatan sipil (Dirjen Dukcapil) Kementerian Dalam Negari RI. Selengkapnya lihat Dian Erika Nugraheny, Data kependudukan 2020: Penduduk Indonesia 268.583.016 Jiwa, http://amp.kompas.com/nasional/read/2020/08/12/ 15261351/data-kependudukan-2020-pendudukindonesia-268583016-jiwa, diakses pada 27 November 2020 pukul 13.15 WIB

${ }^{4}$ Abdurrahman,Masalah Hak-Hak Atas Tanah dan Pembebasan Tanah di Indonesia, cet. 2, Alumni, Bandung,1983, hlm. 1. 
dalam skala yang lebih besar yakni pemanfaatan untuk kesejahteraan rakyat. ${ }^{5}$

Dalam pengadaan tanah untuk pembangunan kepentingan umum, Tanah menjadi faktor terpenting dan menjadi faktor penentu dalam pengadaan tanah untuk kepentingan umum, ${ }^{6}$ Pengadaan tanah untuk kepentingan umum merupakan salah satu kewajiban yang harus dilakukan oleh pemerintah sebagai manifestasi perwujudkan memberikan kesejahteraan bagi rakyatnya dalam hal yan berkaitan dengan kepentingan umum yang harus dinikmani untuk seluruh lapisan sosial kemasyarakatan.

Bahwa bumi dan air serta kekayaan alam yang terkandung di dalamnya dikuasai oleh negara dan dipergunakan sebesar-besarnya untuk kemakmuran rakyat. Dari ketentuan dasar ini dapat diketahui bahwa kemakmuran masyarakatlah yang menjadi tujuan utama dalam pemanfaatan fungsi bumi, air dan ruang angkasa serta kekayaan alam yang terkandung di dalamnya. ${ }^{7}$

Pengadaan tanah untuk kepentingan umum yang dilakukan oleh pemerintah bukan suatu persoalan mudah yang dapat dilakukan begitu saja, dalam melakukan

\footnotetext{
5 Achmad Rubaie, Hukum Pengadaan Tanah Untuk Kepentingan Umum, Bayumedia Publishing, Malang, 2007,hlm. 1

6 I Wayan Suandra, Hukum Pertanahan Indonesia, cet. 1, PT. Rineka Cipta, Jakarta, 1994, hlm.11

7 Pasal 33 Ayat 3 Undang-Undang Dasar Negara Republik Indonesia Tahun 1945
}

pengadaan tanah untuk kepentingan umum banyak peroalan-persoalan yang dihadapi pemerintah seperti pelepasan tanah, pelepasan hak, termasuk juga ganti kerugian atas tanah seseorang yang menjadi salah satu tanah yang hendak digunakan dalam pengadaan tanah untuk kepentingan umum. Proses pengadaan tanah untuk kepentingan umum membutuhkan proses yang panjang agar pelaksanaan pengadaan tanah tersebut tidak menimbulkan kerugian yang besar bagi masyarakat, oleh karenanya hukum harus dapat menjawab dan menyeimbangkan kepentingan umum dan hak-hak dari seseorang yang tanahnya menjadi objek dari pengadaan tanah untuk kepentingan umum.

Pemerintah dalam hal ini telah menerbitkan regulasi atau Peraturan Perundang-undangan berupa Peraturan Presiden Nomor 65 Tahun 2006 tentang Perubahan Kedua Atas Peraturan Presiden Nomor 36 Tahun 2005 tentang Pengadaan Tanah bagi Pelaksanaan Pembangunan untuk Kepentingan Umum. Ketentuan ini mencabut ketentuan lama yakni mencabut Keputusan Presiden Nomor 55 tahun 1993 yang dinilai sudah tidak sesuai dengan kebutuhan dan menangani tantangan masa kini atas pengadaan tanah untuk kepentingan umum. Perpres ini menjadi salah satu alas dasar bagi pemerintah untuk melakukan pengadaan tanah untuk kepentingan umum. 
Pengadaan tanah adalah setiap kegiatan untuk mendapatkan tanah dengan cara memberikan ganti rugi kepada yang melepaskan atau menyerahkan tanah, bangunan, tanaman, dan benda-benda yang berkaitan dengan tanah. ${ }^{8}$

Dalam melakukan pengadaan untuk kepentingan umum nyatanya tidak pernah lepas dari persoalan sengketa, yakni sengketa tanah itu sendiri yang diakibatkan oleh pengadaan tanah.Beberapa sengketa tanah tersebut menjadi salah satu hambatan dalam pembangunan yang hendak dilakukan oleh pemerintah dalam melakukan pengadaan tanah untuk kepentingan umum. Sengketa-sengkta yang dimaksudkan tersebut tidak terlepas dari pemetaan atau penentuan lokasi atas tanah yang akan dilakukan untuk keperluan kepentingan umum,maka menarik pula sebelum meranjak permsalaan atau penyelesaian tanah atas pengadaan untuk kenetingan umum, dalam tulisan ini juga diulas menangani penetuan lokasi atas pengadaan tanah untuk kepentingan umum.

Pemerintah memerlukan cara untuk mengatasi persoalan sengketa yang dihadapinya dalam melakukan pembebasan lahan dalam hal pengadaan tanah untuk kepentingan umum. Dengan demikian

\footnotetext{
8 Pasal 1 Ayat 3 Peraturan Presiden Nomor 65 Tahun 2006 tentang Perubahan Kedua Atas Peraturan Presiden nomor 36 Tahun 2005 tentang Pengadaan Tanah bagi Pelaksanaan Pembangunan untuk Kepentingan Umum
}

penyelesaiakan sengketa manjadi unsur yang menentukan keberhasilan dalam melakukan pengadaan tanah untuk kepentingan umum. Dalam tulisan ini, selanjutnya akan dibahas bagaimana pemerintah menyelsaikan sengketa yang timbul atas pengadaan tanah untuk kepentingan umum (secara non litigasi dan litigasi).

\subsection{Rumusan Masalah}

Berdasarkan uraian tersebut diatas, maka akan ditarik sebuah rumusan masalah. Pertama, bagaimana proses musyawarat dalam menentukan lokasi dan ganti kerugian atas pengadaan tanah untuk kepentingan umum, Kedua, bagaimana penyelesaian sengketa pengadaan tanah untuk kepentingan umum diluar pengadilan dan di pengadilan.

\section{METODEPENELITIAN}

Karya tulis ini merupakan sebuah penelitian hukum normatif terkait kejelasan makna atau interpretasi pemaknaan atas pengadaan tanah untuk kepentingan umum Pasal 1 Angka 3 Peraturan Presiden Nomor 65 Tahun 2006 tentang Perubahan Kedua Atas Peraturan Presiden nomor 36 Tahun 2005 tentang Pengadaan Tanah bagi Pelaksanaan Pembangunan untuk Kepentingan Umum. Penelitian hukum normatif ini juga termasuk menganalisa bagaimana penanganan penyelesaian sengketa 
yang ditimbulkan akibat dari pengadaan tanah untuk kepentingan umum dengan pendekatan normatif.

\section{PEMBAHASAN}

Pertama, untuk menjawab permasalhan pertama, penulisa akan memulai uraiannya mengenai dua hal besar yakni pengadaan tanah dan kepentingan umum. Selanjutnya dalam pembahasan rumusan masalah pertama ini akan dilanjutkan mengenai alur musyawarah penentuan lokasi tanah yang hendak dijadikan atau ditetapkan menjadi lokasi pengadaan tanah untuk kepentingan umum.

Menurut Dujhaendah Hasan Pengadaan tanah ialah suatu kegaiatan atau cara untuk mendapatkan tanah seseorang dengan metode atau cara ganti rugi atas pelepasan tanah, baik tanah kosong, tanah yang terdapat bangunan, tanaman dan benda-benda lain yang ada diatas tanah. ${ }^{9}$ Sedangkan dari segi pengertain yang dimaksudkan berdasarkan Perpres pengadaan tanah ialah:

Pengadaan tanah adalah setiap kegiatan untuk mendapatkan tanah dengan cara memberikan ganti rugi kepada yang melepaskan atau menyerahkan tanah, bangunan, tanaman, dan benda-benda yang berkaitan dengan tanah. ${ }^{10}$

\footnotetext{
9 Djuhaendah Hasan,Hukum Pertanahan, materi Kuliah Hukum Bisnis Pasca Sarjana UNPAD, 2003,hlm. 48

10 Pasal 1 Ayat (3) Peraturan Presiden Nomor 65 Tahun 2006 tentang Perubahan Kedua Atas
}

Pengadaan tanah untuk kepentingan umum secara hukum dalam dilaksanakan atau dilakukan oleh pemerintah dengan beberapa syarat dan ketentuan yang harus dipenuhi, Keppres Nomor 65 Tahun 2006 tentang Perubahan Kedua Atas Peraturan Presiden Nomor 36 Tahun 2005 tentang Pengadaan Tanah bagi Pelaksanaan Pembangunan untuk Kepentingan Umum secara limitatif memberikan ruang baik Pemerintah Pusat atau Daerah melakukan Pengadaan tanah untuk kepentingan umum, selanjutnya pelaksaan atas pengadaan tanah untuk kepentingan umum bisa menjadi aset pemerintah pusat atau pemerintah daerah. ${ }^{11}$

John Salindiho memberikan definisi mengenai kepentingan umum, kepentingan umum ialah sesuatu kepentingan yang masuk dalam lingkup kebutuhan/kepentingan yang menurut pemerintah hal termasuk merupakan kepentingan bersama bangsa dan negara dengan memperhatikan

Peraturan Presiden Nomor 36 Tahun 2005 tentang Pengadaan Tanah bagi Pelaksanaan Pembangunan untuk Kepentingan Umum

${ }^{11}$ Bidang-bidang tertentu yaang dapat dilakukan pemerintah atau pemerintah daerah ialah pengadaan tanah untuk kepentingan umum pada bidang a. Jalan umum dan jalan tol, rel kereta api, saluran air minum/air bersih, saluran pembuangan air dan sanitasi, b. waduk, bendungan, bendungan irigasi dan bangunan pengairan lainnya, c. Pelabuhan, bandar udara, stasiun kereta api, dan terminal, d. fasilitas keselamatan umum, seperti tanggulpenaggulangan banjir, laar dan lan-lain bencana, e. tempat pembuangan sampah, f. Cagar alam dan cagar budaya, g. pembangkit, tranmisi, distribusi tenaga listrik. 
segi-segi lain semisal pertahanan keamanan nasional. $^{12}$

"Untuk kepentingan umum, termasuk kepentingan bangsa dan negara serta kepentingan bersama dari rakyat, hakhak atas tanah dapat dicabut, dengan memberi ganti kerugian yang layak dan menurut cara yang diatur dengan undang-undang". ${ }^{13}$

Berdasarkan doktrin dan pengertian tersebut diatas, maka secara tegas tanah-tanah yang ada diwilayah negara kesatuan RI memiliki fungsi sosial. Fungsi sosial disini ialah negara atau pemerintah dapat mencabut tanan yang ada pada seseorang demi kepentingan umum (kepentingan yang lebih luas bagi masyarakat), ${ }^{14}$ inilah yang membedakan antara ciri sebuah negara kesejateraan (walfare state) ${ }^{15}$ dengan negara penjaga malam.

12 John Salindeho, Masalah Tanah dalam Pembangunan, Cetakan Kedua Sinar Grafika, Jakarta, 1998,hal. 40

13 Pasal 18 Undang-Undang Nomor 5 Tahun 1960 tentang Peraturan Dasar Pokok-Pokok Agraria

${ }^{14}$ Bagi penulis, pemahaman mengenai pemerintah dapat mencabut hak atas tanah dari seseornag arus dimaknai secara komprehensif. Pemaknaan tersebut ialah tidak serta merta hak atas tanah yang dimiliki oleh seseorang dapat serta merta dicabut oleh pemerintah dengan dalih untuk kepentingan umum, tanah yang bisa ditarik oleh pemerintah dengan dalih untuk kepentingan umum harus dilakukan secara cermat dan terukur, cermat dan terukur ialah sesuatu keadaan penentuan keputusan oleh pemerintah yang dilakukan secara hati-hati apakah tanah yang ditetepkan untuk kepentingan umum tersebut benar-benar akan mendatangkan kesejahteraan bagi kepentingan umum,serta tentu pencabutan atas tanah tersebut dilakukan dengan kompensasi atau ganti rugi pembayaran tanah sesuai harga yang proporsional.

${ }^{15}$ Negara yang bisa ikut campur/intervensi demi sebuah kepentingan yang lebih besar/luas, hak
Dalam hal pegadaan tanah untuk kepentingan umum terdapat atau terjadi seuatu konflik atau sengketa mengenai besaran ganti rugi yang akan diterima oleh pemilik hak, maka pemerintah dalam hal ini panitia yang telah ditunjuk untuk melakukan kegiatan pengadaan tanah untuk kepentingan umum hal pertama yang dilakukan ialah dengan cara musyawarah. Musyawarah merupakan satu-satunya dan pertama yang harus dilakukan oleh panitia pengadaan tanah untuk kepentingan umum.

Hal tersebut telah diperintahkan secara jelas dan tegas di dalam Peraturan Presiden Nomor Nomor 65 Tahun 2006 tentang Perubahan Kedua Atas Peraturan Presiden Nomor 36 Tahun 2005 tentang Pengadaan Tanah bagi Pelaksanaan Pembangunan untuk Kepentingan Umum pada Pasal 8 ayat 1 dan 2 . Musyawarah yang dilakukan oleh panitia pengadaan tanah setidaknya beragendakan 2 hal besar yakni, penetapan lokasi serta penetapan besaran ganti kerugi$\mathrm{an}^{16}$ atas tanah yang hendak dilakukan pembebasan tanah untuk kepentingan umum.

(1) Pengadaan tanah bagi pelaksanaan pembangunan untuk kepentingan umum dilakukan melalui musyawarah dalam

pribadi diakui namun tidak mutlak (melalui hukum hak tersebut bisa ditarik/dihapuskan)

${ }^{16}$ Ganti kerugian adalah penggantian yang layak dan adil kepada pihak yang berhak dalam proses pengadaan tanah, selengkapnya lihat pasal 1 angka 10 Peraturan Presiden Republik Indonesia Nomor 71 tahun 2012 tentang Penyelenggaraan Pengadaan Tanah untuk Kepentingan Umum. 
rangka memperoleh kesepakatan mengenai:

a. pelaksanaan pembangunan untuk kepentingan umum di lokasi tersebut; $b$. bentuk dan besarnya ganti rugi.

(2) Musyawarah dilakukan di tempat yang ditentukan dalam surat undangan. $^{17}$

Menurut penulis, adanya konfik sebenarnya sudah mulai tampakpada saat alur pengadaan tanah untuk kepentingan umum ini sejak awal, adanya musyawarah awal ini dalam beberapa praktek didapati sesutau hal yang saklek, terutama mengenai besaran ganti rugi yang akan diterima masyarakat atas pengadaan tanah yang akan dilakukan oleh pemerintah, pada tahapan ini pemerintah melalui panitia ${ }^{18}$ pengadaan tanah untuk kepentingan umum sudah dapat membaca sumber konfilik dan presentasi masyarakat yang setuju dan tidak setuju akan adanya pengadaan tanah untuk kepentingan umum (baik terhadap lokasi/ penetapan tanah atau besaran ganti rugi).

\footnotetext{
${ }^{17}$ Pasal 8 ayat (1) dan (2) Peraturan Presiden Nomor Nomor 65 Tahun 2006 tentang Perubahan Kedua Atas Peraturan Presiden Nomor 36 Tahun 2005 tentang Pengadaan Tanah bagi Pelaksanaan Pembangunan untuk Kepentingan Umum

${ }^{18}$ Sebelum musyawarah dua arah dilakukan pemerintah membentuk panitia pengadaan tanah untuk kepentingan umum, terhadap pengadaan tanah untuk kepentingan umum yang berada di wilayah kabupaten/kota maka pemerintah meminta bantuan panitia pengadaan tanah kabupaten/kota yang dibentuk oleh bupati/ walikota. Keberadaan panitia pengadaan tanah ini sangat penting mengingat salah satu tugasnya ialah mengadakan penelitian mengenai status hukum tanah yang hendak dibebaskan dan menaksir serta mengusulkan besaran gantirugi tanah.
}

Penyelesaian sengketa diluar pengadilan ini dimaksudkan agar semua stakeholder dapat dilibatatkan. Seluruh orang yang memilki kepentingan khsusunya orang-orang yang memilki tanah yang berdasarkan keputusan panitia pengadaan tanah termasuk dalam tanah yang harus dilepaslan haknya, maka cara musyawarahlah yang harus benar-benar dioptimalkan.

Disini dibutuhkan orang-orang yang memilkikesabaran yang tinggi oleh sebab setiap pemilik tanah menyampaikan ekpresi keinginan dan penolakannya yang berbedabeda, terhadap orang-orang yang keras maka cara yang dibuthkannya dengan cara pembicaraan yang intens, maksunya ialah tidak selalu meamksakan kehendak yang jawabannya harus di dapatkan pada waktu itu dengan seketika.

Musyawarah yang dilakukan oleh panitia pengadaan tanah disini harus dilakukan secara langsung oleh panitia pengadaan tanah dengan pemilik hak-hak atas tanah tersebut, artinya ada komunikasi langsung dalam bermusyawarah dalam menetukan lokasi dan penetapan besaran ganti kerugian.Namun dalam keadaankeadaan tertentu dalam hal pemilik tanah yang jumlahnya tidak memungkinkan untuk bisa bertemu langsung maka hal tersebut bisa dilakukan kuasa/kuasa bermusyawarah terhadap orang-orang yang ditunjuk dengan sepengetahuan dari kepala desa atau lurah setempat. 
Pasal 9 Ayat (1) Musyawarah dilakukan secara langsung antara pemegang hak atas tanah, bangunan, tanaman, dan benda-benda lain yangberkaitan dengan tanah bersama panitia pengadaan tanah, dan instansi Pemerintah atau pemerintah daerah yang memerlukan tanah.

(2) Dalam hal jumlah pemegang hak atas tanah tidak memungkinkan terselenggaranya musyawarah secara efektif, maka musyawarah sebagaimana dimaksud pada ayat (1) dilaksanakan oleh panitia pengadaan tanah dan instansi Pemerintah atau pemerintah daerah yang memerlukan tanah dengan wakil-wakil yang ditunjuk di antara dan oleh para pemegang hak atas tanah, yang sekaligus bertindak selaku kuasa mereka.

(3) Penunjukan wakil atau kuasa dari para pemegang hak sebagaimana dimaksud pada ayat (2) harus dilakukan secara tertulis, bermaterai cukup yang diketahui oleh Kepala Desa/Lurah atau surat penunjukan/kuasa yang dibuat di hadapan pejabat yang berwenang.

(4) Musyawarah sebagaimana dimaksud pada ayat (1) dan ayat (2) dipimpin oleh ketua panitia pengadaan tanah. ${ }^{19}$

Terakhir, apabila proses pengadaan tanah yang telah dijelaskan terebut diatas dilalui dan tidak menemui kendal, dan didapati sebuah kesepakatan bersama antara panitia pengadaan tanah dengan masyarakat pemegang hak atas tanah maka panitia pengadaan tanah akan menetapkan sebuah

19 Pasal 9 Ayat (1) Peraturan Presiden Nomor Nomor 65 Tahun 2006 tentang Perubahan Kedua Atas Peraturan Presiden Nomor 36 Tahun 2005 tentang Pengadaan Tanah bagi Pelaksanaan Pembangunan untuk Kepentingan Umum keputusan. Keputusan tersebut meruakan keputusan musyawarat bersama yang telah disepakati terkait hal lokasi yang menjadi bagian dari pengadaan tanah untuk kepentingan umum serta besaran ganti rugi yang akan didapatkan oleh pemegang hak atas tanah yang menjadi objek pengadaan tanah untuk kepentingan umum.

Kedua, akan mejawab permasalahan yang kedua yang akan dimulai dari ulasan mengenai beberapa teori penyelelesaian pengadaan tanah untuk kepentingan umum yakni secara non litigasi dan litigasi.Panitia pengadaan tanah untuk kepentingan umum pertama kali wajib menyelesaiakan persoalan atau sengketa yang timbul atas pengadaan tanah untuk kepentingan umum dengan cara non litigasi atau cara diluar pengadilan. Penyelesaain sengketa pengadaan tanah diluar pengadilan arus menjadi dasar awal penyesaian sengkata yang timbul. Peran dari kepala daerah baik bupati atau walikota wajib hadir untuk menengahi antara panitia pengadaan tanah dengan masyarakat yang memegang hak atas tanah yang terkena objek pengadaan tanah untuk kepentingan umum.

Berdasarkan permasalahan yang ada setidaknya akan ada 2 teori yang digunakan dalam membahas persoalan tersebut, kedua teori tersebut ialah teori litigasi dan teori non litigasi.

Setiap perdamaian hanya mengakhiri perselisihan yang termaktub di dalamnya, 
entah para pihak merumuskan maksud mereka secara khusus atau umum, entah maksud itu dapat disimpulkan sebagai akibat mutlak dari apa uang ditulis itu. ${ }^{20}$

Diantara pihak-pihak yang bersangkutan, suatu perdamaian mempunyai kekuatan seperti suatu keputusan Hakim pada tingkat akhir.Perdamaian itu tidak dapat dibantah dengan alasan bahwa terjadi kekeliruan mengenai hukum atau dengan alasan bahwa salah satu pihak dirugikan. $^{21}$

Sedangkan untuk teori litigasi atau teori penyelesaian sengketa melalui persidangan atau litigasi ialah sistem penyelesaian sengketa melalui lembaga peradilan. Pendekatan ini merupakan suatu pendekatan untuk mendapatkan keadilan melalui sistem perlawanan (the adversary system) dan menggunakan paksaan (coercion) dalam mengelola sengketa serta menghasilkan suatu keputusan win-lose solution bagi pihak-pihak yang bersengketa. $^{22}$

Panitia pengadaan tanah harus paham dan karakter dari masyarakat yang hendak melepaskan tanahnya tersebut, panitia pengadaan tanah harus tau inti pokok persoalan bagi masyarakat tidak mau melepaskan tanahnya tersebut baik karena memang tidak bersedia untuk tidak melepas-

\footnotetext{
${ }^{20}$ Pasal 1855 KUH Perdata

21 Pasal 1858 KUH Perdata

22 Adi Sulistyono, Mengembangkan Paradigma Non-Litigasi di Indonesia, Lembaga Pengembangan Pendidikan (LPP) UNS dan UPT Penerbitan dan Percetakan UNS (UNS Press), Surakarta,2007, hlm. 3-4
}

kan atau mengenai halganti kerugian yang tidak disepakati. Dalam hal masyarakat tidak mau melepaskan hak atas tanahnya yang berdalih bukan karena persoalan besaran ganti rugi, penitia pengadaan tanah bisa memberikan solusi atau alternatif atas persoalan tersebut, misalnya dengan penggantian tanah lain yang berada di lokasi yang berbeda.

Persoalan utama yang biasa muncul ialah enggannya masyarakat melepaskan hak atas tanahnya tersebut bukan masalah besaran ganti rugi tetapi persoalan tanah yang menjadi objek pengadaan tanah untuk kepentingan umum tersebut sudah menjadi mata pencaharian utama dari masyarakat, sehingga cara yang paling ampuh ialah panitia dapat memberikan alternatif penggantian tanah yang hendak dilepaskan tersebut dengan pengganti tanah yang tidak mengurasi kualitas dari tanah masyarakat yang hendak dilepaskan oleh masyarakat tersebut. Bupati atau walikota dapat memaikan perannnya sebagai kepala daerah untuk membantu panitia pengadaan tanah untuk kepentingan umum untuk mencarikan solusi penggantian atas tanah masyarakat tersebut.

Golongan masyarakat yang tidak bersedia melepaskan tanah yang menjadi objek tanah untuk kepentingan umum dalam hal tidak disetujuinya besaran ganti rugi atas pelepasan tanah juga harus dilakukan dengan cara non litigasi atau 
msuyawarah. Panitia pengadaan tanah untuk kepentingan umum arus memberikan waktu (demi kepastian hukum) untuk memberikan waktu yang cukup bagi masyarakat untuk melakukan negoisasi yang proporsional terkait besaran ganti kerugian dimaksud. ${ }^{23}$

Lembaga peradilan adalah sebuah lembaga kekuasan kehakiman yang memilki tugas memeriksa mengadiki dan memutus perkar-perkara yang masuk untuk menyelsaikan konflik anatar dua belak pihak atau lebih. Putusan lembaga peradilan ini ditujukan untuk mengakhiri konflik yang ada, namun dalam hal pengadaan tanah untuk kepentingan umum yang dilakukan dengan cara atau melalui pengadilan tidak seperti pengadili masalah-masalah/sengketa pada umumnya, pengadilan disini hanya sebatas sebuah organ atau lembaga yang berdasarkan ketentuan peraturan perundang-undangan ditugasi menerima titipan besaran ganti kerugian dari panitia pengadaan tanah untuk pembangunan kepentingan umum.

Lembaga peradilan Pangadilan memposisikan diri pasif dalam hal ini, artinya pengadilan negeri hanya menunggu dating-

\footnotetext{
${ }^{23}$ Besaran kerugian atas nilai tanah tidak terlepas dari harga taksiran pada saat hendak dilakukan pengadaan tanah untuk kepentingan umum, Nilai Jual Objek Pajak (NJOP) yang berlaku pada kawasan/daerah yang terkena pengadaan tanah untuk kepentingan umum, serta mempertimbangkan finansial atau keuangan dari pemerintah.
}

nya panitia pengadaan tanah untuk kepentingan umum yang hendak menitipkan basaran ganti kerugian atas pelepasan hakatas tanah yang tanahnya tersebut termasuk dalam lokasi penetapan pengadaan tanah untuk kepentingan umum.Hal ini disebabkan oleh karena ada sebagaian atau beberapa orang yang tanahnya termasuk dalam pengadaan tanah untuk kepentingan umum tidak mau atau tidak sepakat dengan besaran yang dimusyawaahkan bersama, akhirnya peraturan perundang-undangan yang esensi peruntukannya demi kesejahteraan bersama bangsa Indonesia ini menggunakan mekanisme yang demikian.

Sedangkan dalam hal penggantian kerugian yang masuk dalam ranah ganti rugi disini ialah mencakup ganti rugi atas hakatas tanah, bangunan, tanaman dan benda-benda lain yang berada diatas tanah. Bentuk ganti kerugiannyapun sebenarnya di dalam msuyawarah setidaknya ada bentuk 3 (tiga) kegugian yakni uang, tanah pengganti atau pemukiman. Namun dalam hal penitipan ganti kegugian yang terjadi saat ini berupa ganti kerugian yang berupa atau bernilai uang, sedangkan ganti kerugian tanah pengganti atau pemukiman kembali biasanya sudah terjadi kesepakan sebelumnya sehingga hal tersebut tidak sampai ke pengadilan negeri (namun hal tersebut tidak menjadi keharusan, bisa saja ganti kerugian berupa tanah, dan pemukiman juga di- 
mungkinkan dititipkan di pengadilan negeri).

Musyawarah untuk mengatasi konflik atau sengketa atas pelepasan hakatas tanah yang akan digunakan untuk pembangunan kepentingan umum ini harus dilakukan secara optimal dan sungguh-sungguh, karena cara kedua dengan menitipkan besaran ganti kerugian di Pengadilan Negeri merupakan cara terakhir apabila cara musyawarah benar-benar tidak tercapai. Namun biasanya dalam hal musyawarah tentang pangadaan tanah ada beberapa saja yang tidak sepakat dengan musyawarah yang diadakan dengan dalih besaran ganti kerugian yang menurutnya tidak pantas.

Dalam beberapa kasus yang ada sepanjang pengadaan tanah untuk kepentingan umum, yang terjadi ada benar-benar terjadi sengketa yang diselesaikan oleh Pengadilan Negeri, namun yang dalm hal ini adalah terkait sengeketa kepemilikan.Tanah yang telah ditetapkan menjadi bagian lokasi pengadaan tanah untuk kepentingan umum selanjutnya dalam perjalanan musyawarah tidak disepakati menegnai besaran ganti kerugiannya, seperti yang telah dijelaskan sebelumnya maka ganti kerugian tersebut dititipkan oleh penitia pengadan tanah untuk kepentingan umum kepada pengadilan negeri setempat yang menjadi wilayah hukumnya. Namun bagaiman jika ada sengketa kepemilikan akan tanah tersebut?
Pengadilan Negeri dalam hal ini tidak akan mengeluarkan titipan uang pengganti atas tanah yang telah ditetapkan menjadi salah satu alas hak yang harus dilepaskan untuk kepentingan umum, namun pengadilan negeri berhak menahannya terlebih dahulu sebelum diketahui dengan yang sebenarnya terkait siapa pemilik tanah yang sebenarnya. Dengan demikian uang titipan tersebut dalam kekuasaan pengadilan negeri dan baru bisa dikeluarkan kepada pemegang hak jika sudah terbukti siapa pemegang hak atas tanah tersebut.Dengan demikian ada perkara perdata yang harus selesai terlebih dahulu yang itu juga disidangkan di Pengadilan Negeri yang masuk wilayah hukum penetapan lokasi pengadaan tanah untuk kepentingan umum.

Teori litigasi dan non litigasi memainkan perannya dalam hak terjadi saling klaim hak tersebut, seseorang dapat menyelesaikan persoalan tersebut dengan jalur non litigasi/perdamaian tentang pemegang hak yang sesungguhnya untuk mendapatkan win win solution yang saling menguntungkan bagi para pihak. Namun apabila jalur non litigasi tidak didapatkan hasilnya maka penyelesaiannya harus dilakukan dengan cara penyelesaian litigasi atau jalur pengadilan.

Pemerintah harus benar-benar cermat untuk menetukan lokasi dan peruntukan tanah untuk kepentingan umum, diperlukan kajian yang mendalam dan komprehensif, 
pengadaan tanah untuk kepentingan umum harus benar-benar mendatangkan manfaat bagi negara dan masyarakat, sebab dalam beberapa hal (pembangunan bandar udara) sampai tulisan ini dibuat, bandara tersebut sepi dari penumpang karena adanya kesalahan menetukan lokasi atau hal-hal lain yang membuat pengadaan tanah untuk kepentingan umum berpabandara tersebut tidak efektif. Terhadap kepala daerah wajib membantu menengahi proses penyelesaiaan dan sebisa mungkin dapat diselesaikan dengan cara musyawarah agar tidak menimbulkan kerugian baik dari masyarakat atapun dari pemerintah.

\section{KESIMPULAN}

Pada prinsipnya Pengadaan tanah untuk kepentingan umum bisa dilakukan oleh pemerintah demi menciptakan kesejahteraan bagi masyarakat, pengadaan tanah untuk kepentingan umum diawali dengan dibentuknya sebuah panitia pengadaan tanah untuk kepentingan umum yang kemudian bertugas melakukan inventarisasi status tanah dan menaksir harga tanah. Panitia pengadaan tanah untuk kepentingan umum selanjutnya mengundang seluruh masyarakat yang tanahnya menjadi cakupan pengadaan tanah untuk kepentingan umum untuk bermusyawarah mengenai penentuan lokasi dan menentukan besaran ganti kerugian tanah, pada akhirnya penitia pengadaan tanah untuk kepentingan umum akan mengeluarkan penetapan mengenai lokasi dan besaran ganti kerugian tanah yang menjadi objek pengadaan tanah untuk kepentingan umum.

Pada mulanya panitia pengadaan tanah wajib menyelesaikan persoalan yang timbul dengan cara-cara musyawarah dan non litigasi, apabila cara-cara tersebut tidak dapat dilaksanakan maka pengadaan tanah untuk kepentingan umum tetap terlaksana dengan menitipkan besaran ganti kerugian pelepasan tanah dengan cara menitipkan besaran ganti kerugian tersebut pada Pengadilan Negari yang berada pada wialayah hukum pengadaan tanah untuk kepentingan umum. Teradap sengketa kepemilikan maka wajib diselesaiakan secara keperdataan oleh para pihak-pihak yang mengklaim tanah tersebut. 


\section{DAFTAR PUSTAKA}

\section{Buku-Buku:}

Abdurrahman, Masalah Hak-Hak Atas Tanah dan Pembebasan Tanah di Indonesia, cet. 2, Alumni, Bandung, 1983.

Achmad Rubaie, Hukum Pengadaan Tanah Untuk Kepentingan Umum, Bayumedia Publishing, Malang, 2007.

Adi Sulistyono, Mengembangkan Paradigma Non-Litigasi di Indonesia, Lembaga Pengembangan Pendidikan (LPP) UNS dan UPT Penerbitan dan Percetakan UNS (UNS Press), Surakarta, 2007.

Boedi Harsono, Hukum Agraria Indonesia, Sejarah Pembentukan UndangUndang Pokok Agraria, Isi dan Pelaksanannya, Djambatan,Jakarta, 2003.

Djuhaendah Hasan, Hukum Pertanahan, materi Kuliah Hukum Bisnis Pasca Sarjana UNPAD, Bandung, 2003.

I Wayan Suandra, Hukum Pertanahan Indonesia, cet. 1, PT. Rineka Cipta, Jakarta,1994.
John Salindeho, Masalah Tanah dalam Pembangunan, Cetakan Kedua Sinar Grafika, Jakarta,1988.

\section{Internet:}

Dian Erika Nugraheny, Data kependudukan 2020: Penduduk Indonesia 268.583.016Jiwa, http://amp.kompas.c om/nasional/read/2020/08/12/152613 51/data-kependudukan-2020penduduk-indonesia-268583016-jiwa, diakses pada 27 November 2020 pukul 13.15 WIB.

\section{Peraturan Perundang-undangan}

Undang-Undang Dasar Negara Republik Indonesia Tahun 1945.

KUHPerdata

Undang-Undang Nomor 5 Tahun 1960 tentang Peraturan Dasar Pokok-Pokok Agraria

Peraturan Presiden Republik Indonesia Nomor 71 tahun 2012 tentang Penyelenggaraan Pengadaan Tanah untuk Kepentingan Umum.

Peraturan Presiden Nomor Nomor 65 Tahun 2006 tentang Perubahan Kedua Atas Peraturan Presiden Nomor 36 Tahun 2005 tentang Pengadaan Tanah bagi Pelaksanaan Pembangunan untuk Kepentingan Umum 


\section{BIODATA SINGKAT PENULIS}

Muhammad Hoiru Nail adalah Dosen di Program Studi S1 Ilmu Hukum Fakultas Hukum Universitas Islam Jember. Memperoleh Gelar Sarjana Hukum di Universitas Jember tahun 2012. Memperoleh Gelar Magister Hukum di Universitas Jember tahun 2015. Gelar Doktor Ilmu Hukum diperoleh juga dari Fakultas Hukum Universitas Jember pada tahun 2020. 